\title{
Effects of prebiotics and probiotics on the performance and bacterial colonization of broiler chickens
}

\author{
A.M. Abudabos $\#$, H.A. Al-Batshan \& M.A. Murshed \\ Department of Animal Production, College of Food and Agriculture Sciences, King Saud University, Riyadh, \\ Saudi Arabia, P.O. Box 2460, Riyadh 11451, Saudi Arabia
}

(Received 15 February 2015; Accepted 12 June 2015; First published online 29 October 2015)

\begin{abstract}
Copyright resides with the authors in terms of the Creative Commons Attribution 2.5 South African Licence.
See: http://creativecommons.org/licenses/by/2.5/za

Condition of use: The user may copy, distribute, transmit and adapt the work, but must recognise the authors and the South African Journal of Animal Science.
\end{abstract}

\begin{abstract}
A study was undertaken to evaluate the effects of Neoxyval (antimicrobial growth promoter (AGP)), TechnoMos (prebiotic), GalliPro (probiotic) and a mixture of TechnoMos and GalliPro (symbiotic) on growth performance, carcass yield, histomorphology and intestinal bacterial counts in broilers ( $0 \mathrm{~d}$ to $42 \mathrm{~d}$ ). Two hundred day-old Ross (308) broilers were allocated to five experimental treatments: T1 = control (CONT), T2 $=\mathrm{T} 1+$ Neoxyval, T3 = T1 + Gallipro, T4 = T1 + TechnoMos and T5 = T1+ Gallipro+ TechnoMos. The results revealed that birds that received $\mathrm{T} 2, \mathrm{~T} 4$ and $\mathrm{T} 3$ gained more weight and converted feed more efficiently than those in T1 and T5. Longer ileal villi $(492.9 \mu \mathrm{m})$ were recorded in birds that received T4 compared with T1 $(424.7 \mu \mathrm{m})$ and T2 $(439.9 \mu \mathrm{m})$. Conversely, jejunal villi length and width were not influenced by treatment. T3 eliminated Clostridium perfringens from the ileum, but not from the caecum. Generally, birds that received T3 and T5 performed similar to the AGP group, T2. The results from this study indicated that the probiotic (T3) and prebiotic (T4) used in this trial could serve as alternatives to AGP (T2). Enhancement in the performance of broilers could be explained partially by improvement in intestinal morphology and microbial balance associated with modulation of intestinal microflora and inhibition of pathogens.
\end{abstract}

Keywords: Antimicrobial growth promoters (AGPS), broiler performance, prebiotic, probiotic, symbiotic

\# Corresponding author: alabudabos@gmail.com

\section{Introduction}

The use of antibiotics in poultry feed at sub-therapeutic level as an antimicrobial growth promoters (AGP) has been beneficial to growth performance and has reduced the populations in the gastrointestinal tract of potentially pathogenic organisms such as Clostridium perfringens, Salmonella and Escherichia coli and thus diseases associated with these pathogenic bacteria (Hume, 2011). AGPs have routinely been included in poultry feeds (Butaye et al., 2003). However, many antimicrobials given to animals are of the same class as those used to treat human infections, which lead to an increasing concern about crossresistance and multiple antibiotic resistance in pathogenic bacteria. This would pose a risk to public health (Tollefson et al., 1998) with the concern that many antibiotics that are currently available for treating human diseases would not be effective in future (Casewell et al., 2003; Smith et al., 2003; Castanon, 2007). A parallel concern is that the growth of resistance among bacteria would outstrip the ability of the pharmaceutical industry to develop new antibacterial agents. Consequently, the European Union (EU) banned antibiotic use in animal production in 2006.

Current trends in poultry production point to a reduction in or total banning of the use of AGPs, and the need to increase the application of non-antibiotic feed additives that offer similar benefits, such as improving the growth of broilers and utilization of feed (Mountzouris et al., 2007). Several groups of additives are in use such as probiotics, prebiotics, acidifiers, antioxidants and phytogenes.

Probiotics have been reported to prevent pathogenic bacteria such as C. perfringens and Salmonella from colonizing the gut through the mechanism of competitive exclusion (Teo \& Tan, 2006; Abudabos et al., 2013). Another possible alternative to AGPs in poultry diets is the use of prebiotics. 'Prebiotics' refers to oligosaccharides, which are not digested by animal enzymes, but can selectively stimulate certain intestinal bacteria species, which have potentially useful effects on the health of the host. Prebiotics have more advantages than probiotics. While probiotics are intended to bring beneficial microbes to the gut, prebiotics are thought to selectively stimulate the beneficial microbes that already live there (Yang et al., 2009). A third 
alternative to AGPs is symbiotics, which is a combination of probiotics and prebiotics promoting substances, which exhibits a combined effect on the health of the digestive tract, digestibility and the performance of broilers (Patterson \& Burkholder, 2003). The objective of the current study was to examine the effects of prebiotics, probiotics and symbiotics on growth performance in broilers.

\section{Materials and Methods}

Ross 308 broiler chicks were obtained from a commercial hatchery. On arrival, chicks were grouped by weight to reduce variations in mean bodyweight. A total of 200 males and females were distributed among 40 experimental cages. The chicks were vaccinated against Marek's disease, Newcastle Disease and Infectious Bronchitis. Typical iso-energetic and iso-nitrogenous starter (0 - $14 \mathrm{~d})$ and finisher (15 - $42 \mathrm{~d})$ diets, based on maize-soybean meal were formulated in mash form and offered ad libitum (Table 1). At $0 \mathrm{~d}$, birds received one of five dietary treatments: i) T1 $=$ control; ii) T2 $=$ control $+0.05 \mathrm{~g} \mathrm{Neoxyval} / \mathrm{kg}$; iii) $\mathrm{T} 3=$ control + $0.2 \mathrm{~g}$ GalliPro $/ \mathrm{kg}$; iv) T $4=$ control + $0.75 \mathrm{~g}$ TechnoMos $/ \mathrm{kg}$ and v) T $5=$ control + $0.2 \mathrm{~g} \mathrm{GalliPro} / \mathrm{kg}+$ $0.6 \mathrm{~g} \mathrm{TechnoMos} / \mathrm{kg}$ (Table 2).

Table 1 Dietary composition of broiler chick starter and finisher diets

\begin{tabular}{|c|c|c|}
\hline \multirow{2}{*}{ Ingredients } & \multicolumn{2}{|c|}{ Treatment period $(1-42)$ days } \\
\hline & Starter & Finisher \\
\hline Yellow maize & 62.5 & 69.9 \\
\hline Soybean meal & 31.0 & 26.7 \\
\hline Palm oil & 2.19 & 2.80 \\
\hline Di-calcium phosphate & 2.50 & 2.0 \\
\hline Ground limestone & 0.73 & 0.59 \\
\hline Choline chloride & 0.05 & 0.04 \\
\hline DL-methionine & 0.26 & 0.20 \\
\hline L- lysine & 0.18 & 0.24 \\
\hline Salt & 0.25 & 0.25 \\
\hline Threonine & 0.07 & 0.25 \\
\hline Vitamin, mineral premix ${ }^{1}$ & 0.20 & 0.12 \\
\hline Total & 100 & 100 \\
\hline \multicolumn{3}{|l|}{ Calculated analysis } \\
\hline $\mathrm{ME}, \mathrm{MJ} / \mathrm{kg}$ & 12.56 & 12.98 \\
\hline Crude protein, $\mathrm{g} / \mathrm{kg}$ & 215 & 210 \\
\hline Non-phytate $P, g / k g$ & 5.0 & 4.0 \\
\hline Calcium, g/kg & 10 & 9.0 \\
\hline Lysine, $\mathrm{g} / \mathrm{kg}$ & 12 & 11 \\
\hline Methionine, $\mathrm{g} / \mathrm{kg}$ & 5.5 & 4.7 \\
\hline Sulphur amino acids, g/kg & 9.0 & 8.0 \\
\hline Threonine, $\mathrm{g} / \mathrm{kg}$ & 8.5 & 8.0 \\
\hline
\end{tabular}

\footnotetext{
${ }^{1}$ Vitamin-mineral premix contents per kg: 2400000 IU vitamin A; 1000000 IU vitamin D; 16000 IU vitamin E; $800 \mathrm{mg}$ vitamin $\mathrm{K} ; 600 \mathrm{mg}$ vitamin $\mathrm{B}_{1} ; 1600 \mathrm{mg}$ vitamin $\mathrm{B}_{2} ; 1000 \mathrm{mg}$ vitamin $\mathrm{B}_{6} ; 6 \mathrm{mg}$ vitamin $\mathrm{B}_{12} ; 8000 \mathrm{mg}$ niacin; $400 \mathrm{mg}$ folic acid; $3000 \mathrm{mg}$ pantothenic acid; $40 \mathrm{mg}$ biotin; $3000 \mathrm{mg}$ antioxidant; 80 mg cobalt; 2000 mg copper; 400 mg iodine; 1200 mg iron; 18000 mg manganese; 60 mg selenium; 14000 mg zinc.
}

The experiment was conducted in the environmentally controlled battery room at the Animal Production Department, College of Food and Agriculture Sciences, King Saud University, Saudi Arabia. The chicks were placed in a four-deck cage system and received the experimental diets in electrically heated battery brooders with raised wire floors. Broiler chicks were reared in cages under similar managerial and hygienic conditions with a 24 hour light programme. 
Environmental temperature was set at $33^{\circ} \mathrm{C}$ at the beginning of the trial and decreased to $22{ }^{\circ} \mathrm{C}$ until the end of the experiment. Ambient temperature and relative humidity were concurrently and continuously recorded at three-hour intervals using two data loggers (HOBO Pro Series Data Logger, Model H08-032- 08, Onset Colo., USA) inside the chamber. The average temperature and relative humidity for the whole period were $25.0 \pm 0.26^{\circ} \mathrm{C}$ (SD) and $26.6 \pm 3.30 \%$ (SD), respectively. The study was conducted in November and December 2013, under a protocol approved by King Saud University and complies with the current laws of Saudi Arabia.

Table 2 Inclusion rates of antibiotic, probiotic, prebiotic and symbiotic products in treatments for broilers

\begin{tabular}{llcc}
\hline & \multicolumn{3}{c}{ Inclusion rate $\mathbf{( g / k g})$} \\
\cline { 2 - 4 } Item & Additive & Starter $(\mathbf{d} \mathbf{0}$ to d 14) & Finisher (d 15 to d 42) \\
\hline T1 & Control & 0 & 0 \\
T2 & Neoxyval & 0.05 & 0.05 \\
T3 & Gallipro & 0.2 & 0.2 \\
T4 & TechnoMos & 0.75 & 0.5 \\
T5 & Symbiotic & $0.2+0.6$ & $0.2+0.5$ \\
\hline
\end{tabular}

Feed consumption and bodyweight gain (BWG) were recorded weekly by pen, and feed conversion ratio (FCR) was computed per week. Mortality was checked daily and weight of dead birds was used to adjust FCR. At the conclusion of the trial, eight birds per treatment were selected. After euthanasia, feathers, heads, necks and shanks were removed, and the remaining carcasses were dissected into breast and leg quarters and weighed. The yield percentage of each part was calculated based on dressed weight. At $42 \mathrm{~d}$, the entire gastrointestinal tracts from eight birds per treatment were removed aseptically, the small intestines were weighed, and the total length was measured, then separated into duodenum, jejunum (proximal to Meckel's diverticulum) and ileum (proximal to ileo-caecal junction) and measurements of length and weight for each part were taken. Two-cm-long samples from the proximal of each portion of the small intestine were collected for histology measurements. Samples were fixed in phosphate-buffered formalin for at least $48 \mathrm{~h}$, after which they were embedded in paraffin. Sections of $5 \mathrm{~mm}$ were cut and stained with haematoxylin and eosin. Measurements of height and width were based on at least 10 well-oriented villi per sample, using an IX71 Inverted Olympus Microscope (Eyepiece: WH10X, Objective Lens: 4X) and a PC-based image analysis system (Olympus DP72 Microscope Digital Camera; Olympus NV, Aartselaar, Belgium) with software analysis (cellSens Digital Imaging Software).

Ileal digesta and caecal contents were aseptically emptied into new sterile bags and were kept on ice until time of analysis. Samples were diluted in $0.9 \%$ saline, and $0.1 \mathrm{~mL}$ of each sample was plated in duplicates, using selective agar media to enumerate target bacterial groups (Table 3). C. perfringens was counted on tryptose sulphite cycloserine (TSC) agar (Oxoid CM587) with the addition of SR88 and SR47) (Table 4). Colonies on TSC agar that were suspected to be $C$. perfringens were plated secondarily on blood agar (Garridol et al., 2004). Enterobacteriaceae was isolated on MacConkey agar (Oxoid CM7) after an incubation time of $24 \mathrm{~h}$ in an aerobic atmosphere at $37^{\circ} \mathrm{C}$ (Garridol et al., 2004). Isolates of Enterobacteriaceae and Salmonella were identified by API 20E (bioMérieux Vitek). The API 20E strips were inoculated, incubated at $37^{\circ} \mathrm{C}$ for $18-48 \mathrm{~h}$, and interpreted as recommended by the manufacturer. Results were expressed as $\log _{10}$ colony forming units per gram of sample $\left(\log _{10} \mathrm{CFU} / \mathrm{g}\right)$. Fermentation of carbohydrates was determined using API $50 \mathrm{CHL}$, a standardized system, consisting of 50 biochemical tests to study carbohydrate metabolism by microorganisms. API $50 \mathrm{CH}$ was used in conjunction with API $50 \mathrm{CHL}$ medium to identify Lactobacillus and related genera strips according to the manufacturer's instructions (bioMérieux, Marcy l'Etoile, France). The set-up system was incubated at an appropriate temperature of $35^{\circ} \mathrm{C}$ for $48 \mathrm{~h}$. Bacterial strains were identified based on the fermentation of carbohydrates. Identification tables were prepared as (+/-) according to colour change in the evaluation of the results of API strips reaction. Species designations were identified by evaluating with software identification.

Data were evaluated by ANOVA for a complete randomized block design using the general linear models procedure of SAS software (SAS, 2003). When the ANOVA showed significant differences, Fisher's 
protected test was applied. The overall level for statistical significance was set at $P<0.05$. All values were expressed as means \pm standard error of the mean (SEM).

\section{Results}

Body weight gain, food intake $(\mathrm{FI})$ and mortality corrected FCR of the birds at different ages are shown in Tables 3 - 5. The performance results were measured weekly and cumulatively for starter $(0-14 \mathrm{~d})$, finisher (15 - $42 \mathrm{~d})$ and starter and finisher (0 - $42 \mathrm{~d})$.

Table 3 shows the cumulative performance for the starter period (weeks 1 and 2). The results revealed that FI was not affected by any dietary treatments $(P>0.05)$ while BWG and FCR were influenced by dietary treatments $(P<0.05$ and $P<0.05$, respectively). Chicks that received T2 and T4 had the highest BWG (319.9 and $308.3 \mathrm{~g}$, respectively) but it was not different from the gain obtained from those that received T3 (299.7 g). Chicks that received T1 and T5 had the lowest BWG during the two-week period (269.7 and $293.7 \mathrm{~g}$, respectively).

The combined FCR for the first two-week period was the best for chicks that received T2, T3 and T4 (1.278, 1.279 and $1.292 \mathrm{~g} / \mathrm{g}$, respectively) but it was not different from T5 (1.360 g/g). Chicks on T1 (unsupplemented diet) had the worst FCR $(1.451 \mathrm{~g} / \mathrm{g})$.

Table 3 Feed intake (FI), bodyweight gain (BWG) and feed conversion ratio (FCR) of broiler chickens given experimental diets from $\mathrm{d} 0$ to $\mathrm{d} 14$

\begin{tabular}{lccc}
\hline & & Measurements & \\
\cline { 2 - 4 } Treatment & FI (g) & BWG (g) & FCR (g/g) \\
\hline T1 & 384.4 & $269.7^{\mathrm{b}}$ & $1.451^{\mathrm{a}}$ \\
T2 & 408.4 & $319.9^{\mathrm{a}}$ & $1.278^{\mathrm{b}}$ \\
T3 & 383.0 & $299.7^{\mathrm{ab}}$ & $1.279^{\mathrm{b}}$ \\
T4 & 397.7 & $308.3^{\mathrm{a}}$ & $1.292^{\mathrm{b}}$ \\
T5 & 398.9 & $293.7^{\mathrm{b}}$ & $1.360^{\mathrm{ab}}$ \\
SEM & \pm 11.56 & \pm 10.84 & \pm 0.043 \\
P-value & NS & $*$ & $*$ \\
\hline
\end{tabular}

${ }^{\mathrm{ab}}$ means in the same column with different superscripts differ significantly $\left.{ }^{*} P<0.05\right)$; NS: not significant.

Table 4 Feed intake (FI), bodyweight gain (BWG) and feed conversion ratio (FCR) of broiler chickens given experimental diets at different ages ( $d 15$ to $d 42$ )

\begin{tabular}{lccc}
\hline \multirow{2}{*}{ Treatment } & \multicolumn{2}{c}{ Measurements } \\
\cline { 2 - 4 } & FI (g) & BWG (g) & FCR (g/g) \\
\hline T1 & 3066.9 & $1660.2^{\mathrm{c}}$ & $1.852^{\mathrm{a}}$ \\
T2 & 3304.4 & $1922.1^{\mathrm{a}}$ & $1.720^{\mathrm{b}}$ \\
T3 & 3200.6 & $1828^{\mathrm{ab}}$ & $1.752^{\mathrm{b}}$ \\
T4 & 3241.2 & $1854.2^{\mathrm{a}}$ & $1.749^{\mathrm{b}}$ \\
T5 & 3089.8 & $1694.9^{\mathrm{bc}}$ & $1.825^{\mathrm{b}}$ \\
SEM & \pm 77.27 & \pm 47.15 & \pm 0.019 \\
$P$-value & $\mathrm{NS}$ & $* *$ & $* *$ \\
& & &
\end{tabular}

The performance results for the cumulative finisher period (15 - 42 d) showed no significant differences $(P>0.05)$ in $\mathrm{Fl}$ because of treatment (Table 4). BWG was highest for birds that received T2, T4 
and T3 (1922.1, 1854.2 ad $1828 \mathrm{~g}$, respectively), intermediate for birds that received T5 (1694.9) and lowest for the T1 group $(1660.2 \mathrm{~g})(P<0.01)$. The combined FCR for the finisher period was best for chicks that received T2, T4, T3 and T5 $(1.720,1.749,1.752$ and $1.825 \mathrm{~g} / \mathrm{g}$, respectively). Chicks on T1 had the worst FCR for the finisher period $(1.852 \mathrm{~g} / \mathrm{g})$.

Table 5 shows the performance for the cumulative period ( 0 - $42 \mathrm{~d})$. Birds that received T2, T4 and T3 gained more weight than the T1 group (2469.3, 2380, 2338.2 and $2105.0 \mathrm{~g}$, respectively) $(P<0.01)$, while those that had received T5 $(2194.4 \mathrm{~g})$ were intermediate and not significantly different from T3 and T1. On the other hand, birds that received T2, T4 and T3 converted feed more efficiently (1.638, 1.650 and 1.651 $\mathrm{g} / \mathrm{g}$, respectively) compared with those that received T5 $(1.718 \mathrm{~g} / \mathrm{g})$ and T1 $(1.771 \mathrm{~g} / \mathrm{g})(P<0.001)$.

The mean percentage of carcass parts in the various treatments is shown in Table 6 . Treatment had no effect on dressing percentage, breast muscle yield, leg quarter yield and abdominal fat, $(P>0.05)$. However, relative liver weight was influenced by diet. Birds that received T4 had the highest weight of all treatments $(P<0.05)$.

Table 5 Feed intake (FI), bodyweight gain (BWG) and feed conversion ratio (FCR) of broiler chickens given experimental diets from d 0 to $\mathrm{d} 42$

\begin{tabular}{lcccc}
\hline \multirow{2}{*}{ Treatment } & \multicolumn{4}{c}{ Measurements } \\
\cline { 2 - 5 } & FI (g) & BWG (g) & FCR (g/g) & Survival rate (\%) \\
\hline T1 & $3715.1^{\mathrm{b}}$ & $2105^{\mathrm{c}}$ & $1.771^{\mathrm{a}}$ & 98.57 \\
T2 & $4006.1^{\mathrm{a}}$ & $2469.3^{\mathrm{a}}$ & $1.623^{\mathrm{c}}$ & 99.05 \\
T3 & $3859.0^{\mathrm{ab}}$ & $2338.2^{\mathrm{ab}}$ & $1.651^{\mathrm{c}}$ & 99.05 \\
T4 & $3926.3^{\mathrm{ab}}$ & $2380.3^{\mathrm{a}}$ & $1.650^{\mathrm{c}}$ & 98.45 \\
T5 & $3765.4^{\mathrm{ab}}$ & $2194.4^{\mathrm{bc}}$ & $1.718^{\mathrm{b}}$ & 99.52 \\
SEM & \pm 88.81 & \pm 59.58 & \pm 0.018 & \pm 0.66 \\
$P$-value & $\mathrm{NS}$ & $* *$ & $* *$ & $\mathrm{NS}$
\end{tabular}

$\overline{\mathrm{abc}}$ means in the same column with different superscripts differ significantly ( $\left.{ }^{\star *} P<0.01\right)$; NS: not significant.

Table 6 Effects of different treatments on carcass parts as percentages of broiler dressed weight at 42 days old

\begin{tabular}{|c|c|c|c|c|c|c|c|}
\hline & \multicolumn{5}{|c|}{ Treatment } & \multirow{2}{*}{ SEM } & \multirow{2}{*}{$P$} \\
\hline & T1 & T2 & T3 & T4 & T5 & & \\
\hline Dressed yield (\%) & 73.0 & 74.6 & 74.4 & 74.1 & 73.2 & \pm 0.60 & NS \\
\hline Breast $(\%)^{1}$ & 35.2 & 39.2 & 39.4 & 39.2 & 36.6 & \pm 1.41 & NS \\
\hline Leg quarter $(\%)^{1}$ & 43.1 & 40.9 & 41.9 & 41.5 & 42.9 & \pm 1.05 & NS \\
\hline Abdominal fat (\%) & 3.27 & 3.11 & 2.88 & 2.72 & 2.82 & \pm 0.31 & NS \\
\hline Liver (\%) & $2.94^{\mathrm{abc}}$ & $2.63^{c}$ & $2.80^{C}$ & $3.33^{a}$ & $3.10^{\mathrm{ab}}$ & \pm 0.14 & * \\
\hline
\end{tabular}

Breast and leg quarter were expressed as percentage of the carcass weight.

${ }^{a b c}$ means in the row with different. Superscripts differ significantly $(* P<0.05)$; NS: not significant.

Table 7 shows the measurements of intestinal morphology. Jejunal and ileal length were affected by treatment $(P<0.01)$. The longest small intestine (jejunal and ileum) was recorded from birds that received T2 and T3 (151.7 and $151.3 \mathrm{~cm}$, respectively). The shortest small intestine was measured in birds that received T4 $(131.0 \mathrm{~cm})$. However, insignificant differences were found between birds that received T1 $(132.5 \mathrm{~cm})$ and T5 $(142.8 \mathrm{~cm})$. On the other hand, small intestine weight $(\mathrm{g})$, intestinal weight $(\mathrm{g} / \mathrm{cm})$ and intestine relative weight $(\mathrm{g} / 100 \mathrm{~g}$ body weight) were not influenced by treatment $(P<0.05)$. 
Ileal villi height was influenced by treatment $(P<0.001)$. Longer ileal villi were obtained from birds that received T4 $(492.9 \mu \mathrm{m})$ compared with T1 $(424.7 \mu \mathrm{m})$ and T2 $(439.9 \mu \mathrm{m})(P<0.05)$. Insignificant differences were found in ileal villi length between T3 $(454.8 \mu \mathrm{m})$, T5 $(444.9 \mu \mathrm{m})$ and T4 $(492.9 \mu \mathrm{m})$. Conversely, jejunal villi length was not influenced by treatment $(P>0.05)$. Jejunal and ileal villus width were not affected by dietary treatments $(P>0.05)$.

Table 7 Intestinal morphology and histology of broilers at $42 \mathrm{~d}$ old

\begin{tabular}{|c|c|c|c|c|c|c|c|}
\hline & \multicolumn{5}{|c|}{ Treatment } & \multirow{2}{*}{ SEM } & \multirow{2}{*}{$P$} \\
\hline & T1 & T2 & T3 & T4 & T5 & & \\
\hline Jej+lle length (cm) & $132.5^{b c}$ & $151.7^{\mathrm{a}}$ & $151.3^{\mathrm{a}}$ & $131.0^{c}$ & $142.8^{\mathrm{bc}}$ & \pm 3.33 & ** \\
\hline Jejunum length (\%) & 48.7 & 51.0 & 50.3 & 49.9 & 49.5 & \pm 0.98 & NS \\
\hline Ileum length (\%) & 51.3 & 48.9 & 49.7 & 50.0 & 50.5 & \pm 0.98 & NS \\
\hline Jej+lle weight (g) & 33.6 & 41.2 & 37.2 & 34.2 & 33.9 & \pm 2.25 & NS \\
\hline Jejunum weight (\%) & 51.7 & 52.1 & 51.5 & 54.7 & 55.1 & \pm 1.48 & NS \\
\hline Ileum weight (\%) & 48.3 & 47.9 & 48.5 & 45.3 & 44.8 & \pm 0.012 & NS \\
\hline Intestine weight $(\mathrm{g} / \mathrm{cm})$ & 0.42 & 0.27 & 0.25 & 0.26 & 0.24 & \pm 0.03 & NS \\
\hline $\mathrm{IRW}^{\mathrm{A}}(\mathrm{g} / 100 \mathrm{~g} \mathrm{BW})$ & 2.25 & 2.34 & 2.34 & 2.28 & 2.17 & \pm 0.135 & NS \\
\hline \multicolumn{8}{|l|}{ Villus height ${ }^{B}(\mu \mathrm{m})$} \\
\hline Jejunum & 520.9 & 600.1 & 625.2 & 572.6 & 611.6 & \pm 18.22 & NS \\
\hline Ileum & $424.7^{b}$ & $439.9^{b}$ & $454.8^{\mathrm{ab}}$ & $492.9^{\mathrm{a}}$ & $444.9^{\mathrm{ab}}$ & \pm 17.88 & * \\
\hline \multicolumn{8}{|l|}{ Villus width $^{B}(\mu \mathrm{m})$} \\
\hline Jejunum & 66.7 & 69.1 & 74.3 & 72.6 & 67.6 & \pm 2.75 & NS \\
\hline Ileum & 73.7 & 71.9 & 71.4 & 74.2 & 82.9 & \pm 3.47 & NS \\
\hline
\end{tabular}

\footnotetext{
${ }^{A}$ IRW: intestine relative weight.

${ }^{\mathrm{B}}$ Measurements of height and width were based on at least five well-oriented villi per section per broiler for five birds per treatment.

${ }^{\mathrm{abc}}$ means in the row with different superscripts differ significantly $\left({ }^{*} P<0.05\right)$; ${ }^{* *} P<0.01$.
}

Table 8 presents data related to the ileal and caecal bacterial count of broilers. Gram negative Bacilli were found to be the same in the ileum and caecum among all groups $(P>0.05)$, which was an indication that the antibiotic, probiotic, prebiotic and symbiotic tested in this trial had no influence on gram negative bacteria. The probiotic (T3) eliminated $C$. perfringens from the ileum but it did not differ significantly from birds that received T5 (0.0 and $1.15 \mathrm{log}$ CFU/g, respectively). Conversely, $C$. perfringens count in the caecum was not influenced by dietary treatment $(P<0.05)$.

Lactic acid bacteria increased significantly $(P<0.05)$ in the ileum for T4 $(6.87 \mathrm{CFU} / \mathrm{g})$, which was not different from the T2, T3 and T5 groups (5.87, 6.47 and $6.39 \mathrm{CFU} / \mathrm{g}$, respectively), while T1 had the lowest count (5.52 CFU/g). Lactic acid bacteria increased significantly $(P<0.01)$ in the caecum for T2, T3, T4 and T5 groups (6.99, 7.14, 7.11 and 6.93 CFU/g, respectively) compared with T1 group (4.48 CFU/g).

\section{Discussion}

The application of in-feed AGPs in poultry diets threatens consumer health. Resistant microbial populations are the outcome of antibiotic use in poultry. There has been a big push to find alternative treatment methods for common poultry ailments. These include probiotics, prebiotics and symbiotics. The results of the present feeding trial provided evidence that the dietary inclusion of probiotics (T3) and prebiotic (T4) improved the cumulative BWG and FCR of broiler chickens, similarly to the AGP (T2).

The probiotic group performed similarly to the antibiotic group and it was concluded that GalliPro (T3) could replace the antibiotic without any negative effect on bird performance. The results of the current study agree with previous reports (Teo \& Tan, 2006; 2007), which showed that $B$. subtilis based-probiotic improved broiler performance, and explained the improvements by different mechanisms. Mountzouris et al. (2007) 
Table 8 Ileal and caecal bacterial count in broilers at 42 days old (mean, $\log _{10} \mathrm{CFU} / \mathrm{g}$ )

\begin{tabular}{|c|c|c|c|c|c|c|c|}
\hline & \multicolumn{5}{|c|}{ Treatments } & \multirow{2}{*}{ SEM } & \multirow{2}{*}{$P$} \\
\hline & T1 & T2 & T3 & T4 & T5 & & \\
\hline \multicolumn{8}{|l|}{ Ileum } \\
\hline Gram neg. bacilli $*$ & 3.95 & 4.76 & 4.38 & 5.20 & 3.36 & \pm 0.197 & NS \\
\hline C. perfringens & $3.34^{\mathrm{a}}$ & $2.34^{\mathrm{a}}$ & $0.00^{\mathrm{b}}$ & $3.01^{\mathrm{a}}$ & $1.15^{\mathrm{ab}}$ & \pm 0.027 & * \\
\hline Lactic acid & $5.52^{\mathrm{c}}$ & $5.87^{\mathrm{bc}}$ & $6.47^{\mathrm{ab}}$ & $6.87^{\mathrm{a}}$ & $6.39^{\mathrm{ab}}$ & \pm 0.003 & ** \\
\hline \multicolumn{8}{|l|}{ Caecum } \\
\hline Gram neg. bacilli $*$ & 7.42 & 6.54 & 7.08 & 7.04 & 7.12 & \pm 0.17 & NS \\
\hline C. perfringens & 4.48 & 3.35 & 4.44 & 2.81 & 4.33 & \pm 0.11 & NS \\
\hline Lactic acid & $4.48^{\mathrm{b}}$ & $4.30^{\mathrm{b}}$ & $7.14^{\mathrm{a}}$ & $7.11^{\mathrm{a}}$ & $6.93^{\mathrm{a}}$ & \pm 0.003 & ** \\
\hline
\end{tabular}

${ }^{*}$ Gram negative bacilli, ${ }^{\text {abc }}$ means in the row with different superscripts differ significantly $\left({ }^{\star} P<0.05 ;{ }^{\star \star} P<0.01\right)$.

reported that the overall FCR for probiotic treatment was not different from antibiotic treatment. Lund et al. (2005) conducted four feeding trials at various locations in EU between 2003 and 2005 and concluded that B. subtilis improved bodyweight of broilers from $1 \%$ to $7 \%$. Later, Rostagno et al. (2006) examined the efficacy of GalliPro ${ }^{\circledR}\left(8 \times 10^{5}\right.$ CFU B. subtilis/g feed) and an antibiotic supplemented diet (Avilamycin), and concluded that broilers fed GalliPro ${ }^{\circledR}$ performed similarly to those fed the antibiotic diet. However, other reports disagree with the current findings. For example, Kwakernaak et al. (2007) concluded that $B$. subtilis spores supplemented to wheat-SBM diet did not improve cumulative BWG and FCR at d 36.

The prebiotic (T4) improved the performance to a similar level as the AGP. The results revealed a significant improvement in FCR at $42 \mathrm{~d}$ for birds that had received the T4. This could be explained by the significant improvement in BWG, which was associated with birds that received T4. These results are in line with the findings of Podmaniczky et al. (2006) and Rosen (2007). Both groups reported a positive effect for yeast cell wall products on the performance of broilers. Hooge (2003) came to the same conclusion when he analysed the effects of a prebiotic (mannan-oligosaccharides) from 24 trials. It was reported that FCR improved by $2.27 \%$ because of prebiotic supplementation.

Supplementing probiotics (T3) and prebiotics (T4) individually appeared to be superior to symbiotic supplementation (T5) in improving broiler performance. Li et al. (2008) showed that combinations of pre- and probiotics (symbiotics) are often more effective than individual additives. Similarly, Awad et al. (2009) reported beneficial effects of a symbiotic over a probiotic product on broiler performance. However, this was not the case in the current study. When the symbiotic (T5) was used, the performance was lower compared with the individual probiotic (T3) and prebiotic (T5).

Histological examination revealed a significant difference in villi height among the treatment groups at d 42. Birds that received prebiotics (T4), probiotics (T3) and symbiotics (T5) showed improved ileal villi height to a level that was superior to the control (T1) and antibiotic (T2) supplemented groups. These results indicated that changes occurred in villi morphology between treatments during the trial period, and thus increased the absorptive surface area in the small intestine. Longer villi are usually equated with excellent gut health, high absorptive efficiency and healthier intestinal tracts of chickens (Alfaro et al., 2007). According to Cera et al. (1988), maximum absorption and digestion capacity are provided by a large luminal area with villus height and mature enterocytes, and is essential to animal development. Several reports observed greater villi height and superior ileal mucosa development in chickens supplemented with a yeast cell wall product prepared from Saccharomyces cerevisiae, particularly in the first week of the chicken's life (Santin et al., 2001; Zhang et al., 2005). Similarly, Salim et al. (2013) reported that ileal villus height and width were improved when birds were fed probiotics compared with antibiotics and control. On the other hand, antibiotic supplementation caused a decrease in ileal villi height. Similar results were reported by Oliveira et al. (2008), who found that antibiotic supplementation caused low villi height. They explained this by the suppressing effect of the antibiotic on beneficial bacteria in the gut, such as Lactobacillus and Bifidobacteria. Longer villi indicate more mature epithelia and enhanced absorptive function due to increased absorptive area of the villus.

Wilson et al. (2005) explained that the growth-suppressing effect of intestinal bacteria was due to the production of toxic metabolites that irritate the gut mucosa, thereby inhibiting nutrient absorption. Gram negative Bacilli were found to be the same among all groups in the ileum and caecum, which was an 
indication that the antibiotic, probiotic, prebiotic and symbiotic tested in this trial had no influence on gram negative bacteria. According to Bedford (2000), most AGPs target gram positive bacteria, and suggest that this group of bacteria is an important cause of impaired performance. The anticlostridial properties of the antibiotic, prebiotic, probiotic and symbiotic were tested in this study. C. perfringens is known to be a main causative for necrotic enteritis and could cause major health problems to the birds if antibiotics were removed without being replaced with products that could prevent the proliferation of this bacterium (Ficken \& Wages, 1997; Porter, 1998). A subclinical disease associated with necrotic enteritis could damage the intestinal mucosa, which results in a decrease in digestion and absorption and, as a result, poor performance (Kaldhusdal et al., 2001). The growth-suppressing effect of intestinal bacteria was explained by the toxin produced by the bacteria, which could irritate the gut mucosa, thus constraining nutrient absorption. Feighner \& Dashkevicz (1987) explained the growth depression caused by C. perfringens infection was related to the high level of bile salt hydrolase activity in $C$. perfringens. The results show that probiotic supplementation alone (T3) or as part of the symbiotic (T5) controlled the proliferation of $C$. perfringens in the ileum. The probiotic (T3) eliminated $C$. perfringens ( $0.0 \mathrm{log}$ CFU/g) in the ileum, but not in the caecum. This elimination could be explained by competitive exclusion and stimulation of the immune system.

Several studies used a Bacillus subtilis-based probiotic supplement and came to the same conclusions (Jack et al., 1995; Teo \& Tan, 2007). Strains of $B$. subtilis have been shown to eliminate the colonizing of several pathogenic bacteria in the gut, such as E. coli, Salmonella, Clostridium, Streptococcus and Campylobacter (La Ragione et al., 2001; Teo \& Tan, 2006; Knapp et al., 2011). The antimicrobial factor produced by Bacillus subtilis is typical of gram positive bacteriocins in being broadly active against various strains of Clostridium species.

The ileal C. perfringens populations of birds were not altered when the prebiotic (T4) was added to their diets. This disagrees with the findings of Spring et al. (2000) and Yang et al. (2007; 2008), where prebiotics were found to have a positive effect in lowering $C$. perfringens populations. The prebiotic reduction ability of $C$. perfringens was explained by its capability of controlling the pathogens in the small intestine by offering competitive binding sites for undesirable pathogens (Newman, 1994). On the other hand, the improvement in BWG and FCR could be related to the lower microbial population in the gastrointestinal tract in broilers (Thongsong et al., 2008).

Prebiotics are not digested in the small intestine. Therefore, bacteria bound to prebiotics are likely to exit the intestine without attaching to the epithelium and this causes a reduction or prevention of colonization of undesirable bacteria in the small intestine (Spring et al., 2000).

Lactic acid bacteria, which are regarded as good bacteria in the gut, increased in the probiotic (T3), prebiotic (T4) and symbiotic (T5) treatments compared with the control (T1) and AGP (T2) treatments. This finding agrees with those of others. Teo \& Tan (2006) reported that $B$. subtilis produces lactic and acetic acid from glucose. The significant increases in the lactic acid colony counts in the ileum and the caecum in the prebiotic (T4) and probiotic (T3) supplemented groups provide new evidence about changing the intestinal flora through prebiotics and probiotics. Probiotics contain yeast cells, bacterial cultures both that stimulate microorganisms capable of modifying the gastrointestinal environment to a healthy status and improving feed efficiency. Probiotics induce alterations in intestinal flora, enhance the growth of non-pathogenic facultative anaerobic and gram positive bacteria forming lactic acid, and suppress the growth of intestinal pathogens.

\section{Conclusions and Applications}

Poor performance was associated with broilers that did not receive any kind of medication (T1). Birds that received the T3 and T4 performed similarly to the AGP group (T2). The order of treatments based on cumulative FCR results were $\mathrm{T} 1>\mathrm{T} 5>\mathrm{T} 3 \geq \mathrm{T} 4 \geq \mathrm{T} 2$. The combination of the probiotic and the prebiotic (T5) reduced performance compared with each one separately (T3 and T4). The height of intestinal villus is associated with digestion and absorption capacity and could be regulated through dietary means. Ileal villi height reduced in T1 and T2 groups while it was the longest in the T3 and T4 groups. The morphology improvements in the intestinal tract as observed in this study supported the concept that broilers gut health and function can be improved by dietary supplementation such as probiotics and prebiotics. The probiotic eliminated $C$. perfringens from the ileum, while lactic acid increased in the ileum and caecum of broilers because of probiotic and prebiotic supplementation. The probiotic and prebiotic used in this trial could enhance the performance of broilers by improving intestinal morphology and microbial balance associated with modulation of intestinal microflora and pathogen inhibition.

\section{Acknowledgements}

The authors would like to extend their sincere appreciation to the Deanship of Scientific Research at King Saud University for funding this research through Research Group Project No. RGP-VPP-273. 


\section{References}

Abudabos, AM., Alyemni A.H. \& Marshad, M.B., 2013. Bacillus subtilis PB6 based-probiotic (CloSTAT ${ }^{\mathrm{TM}}$ ) improves intestinal morpholgical and microbiological status of broiler chickens under Clostridium perfringens challenge. Int. J. Agric. Biol. 15, 978-982.

Alfaro, D.M., Silva, A.V.F., Borges, S.A., Maiorka, F.A., Vargas, S. \& Santin, E., 2007. Use of Yucca schidigera extract in broiler diets and its effects on performance results obtained with different coccidiosis control methods. J. Appl. Poult. Res. 16, 248-254.

Awad, W.A., Ghareeb, K., Abdel-Raheem, S. \& Bohm, J., 2009. Effects of dietary inclusion of probiotic and synbiotic on growth performance, organ weights, and intestinal histomorphology of broiler chickens, Poult. Sci. 88, 49-56.

Bedford, M., 2000. Removal of antibiotic growth promoters from poultry diets: Implications and strategies to minimize subsequent problems. World's Poult. Sci. J. 56, 347-365.

Butaye, P., Devriese, L.A. \& Haesebrouck, F., 2003. Antimicrobial growth promoters used in animal feed: Effects of less well-known antibiotics on gram-positive bacteria. Clin. Microb. Rev. 16, 175-188.

Casewell, M., Friis, C., Marco, E., McMullin, P. \& Phillips, I., 2003. The European ban on growth-promoting antibiotics and emerging consequences for human and animal health. J. Antimicrobial Chemoth. 52, 159-161.

Castanon, J.I.R., 2007. History of the use of antibiotic as growth promoters in European poultry feed. Poult. Sci. 86, 2466-2471.

Cera, K.R., Mahan, D.C. Cross, R.F. Reinhart, G.A. \& Whitmoyer, R.E., 1988. Effect of age, weaning and postweaning diet on small intestinal growth and jejunal morphology in young swine. J. Anim. Sci. 66, 574-584.

European Commission, 2003. Regulation 1831 of the European Parliament and of the Council of 22 September 2003 on additives for use in animal nutrition. Official Journal of the European Union L $268 / 29$.

Feighner, S.D. \& Dashkevicz, M.P., 1987. Subtherapeutic levels of antibiotics in poultry feeds and their effects on weight gain, feed efficiency, and bacterial cholyltaurine hydrolase activity. Appl. Envir. Micro. 53, 331-336.

Ficken, M.D. \& Wages, D.P., 1997. Necrotic enteritis. In: Diseases of Poultry. Eds: Barnes, H.J., Beard, C.W., McDougald, L.R., Saif, Y.M. \& Calnek, B.W., Iowa State University Press, Ames, IA. pp. 261-264.

Garridol, M.N., Skjervheim, M. Oppegaard, H. \& Sørum, H., 2004. Acidified litter benefits the intestinal flora balance of broiler chickens. Appl. Environ. Micro. 70, 5208-5213.

Hooge, D.M., 2003. Broiler chicken performance may improve with MOS. Feedstuffs 6, 11-13.

Hume, M.E., 2011. Historic perspective: Prebiotics, probiotics, and other alternatives to antibiotics. Poult. Sci. 90, 2663-2669.

Jack, R.W., Tagg, J.R. \& Ray, B., 1995. Bacteriocins of gram-positive bacteria. Microbiol. Rev. 59, 171-200.

Kaldhusdal, M., Schneitz, C., Hofshagen, M. \& Skjerve, E., 2001. Reduced incidence of Clostridium perfringens-associated lesions and improved performance in broiler chickens treated with normal intestinal bacteria from adult fowl. Avian Dis. 45, 149-156.

Knapp, S., Warshow, U., Alexander, K.M., Ho, D., Hegazy, A.M., Fowell, A., Alexander, G.T., Hursz, M., Cramp, M. \& Khakoo, S.I., 2011. A polymorphism in IL28B distinguishes exposed, uninfected individuals from spontaneous resolvers of HCV Infection. Gastroenterol. 141, 320-325.

Kwakernaak, C., Van der Klis, J.D. \& De Gussem, K., 2007. The effect of a pre- and probiotic on the performance of broilers. World Poultry Science Association, Proceeding of the 16th European Symposium on Poultry Nutrition, August 26-30. Strasbourg, France. pp. 565-568.

La Ragione, R.M., Cuttingb, S.M. \& Woodwarda, M.J., 2001. Bacillus subtilis spores competitively exclude Escherichia coli O78:K80 in poultry. Vet. Micro. 79, 133-142.

Li X., Qiang, L. \& Liu, C.H., 2008. Effects of supplementation of fructooligosaccharide and/or Bacillus subtilis to diets on performance and on intestinal microflora in broilers. Arch. fur Tierz. 51, 64-70.

Lund, B., Hansen, S. \& Kürti, P., 2005. "Efficacy of GalliPro-a microbial feed additive for broilers", Proceedings from the 15th European Symposium on Poultry Nutrition, WPSA, 25-29, Belatonfüred, Hungary. pp. 263-265.

Mountzouris, K.C, Tsistsikos, P., Kalamara, E., Nitsh, S., Schatzmayr, G. \& Fegeros, K., 2007. Evaluation of the efficacy of a probiotic containing Lactobacillus, Bifidobacterium, Enterococcus and Pediococcus strains in promoting broiler performance and modulating cecal microflora composition and metabolic activities. Poult. Sci. 86, 309-317. 
Newman, K., 1994. Mannan-Oligosaccharides: Natural polymers with significant impact on the gastrointestinal microflora and the immune system. In: Biotechnology in the Feed Industry. Eds: Lyons, T.P. \& Jacques, K.A., Nottingham University Press, Nottingham, UK. pp. 167-174.

Oliveira, M.C., Rodrigues, E.A., Marques, R.H., Gravena, R.A., Guandolini, G.C. \& Moraes, V.M.B., 2008. Performance and morphology of intestinal mucosa of broilers fed mannan-oligosaccharides and enzymes. Arquivo Brasileiro de Medicina Veterinária e Zoo. 60, 442-448.

Patterson, J.A. \& Burkholder, K.M., 2003. Application of prebiotics and probiotics in poultry production. Poult. Sci. 82, 627-631.

Podmaniczky, B.A., Kocher, Z.S., Vegi, S.B., Korosi, K.H.L. \& Molnar, A.K., 2006. The effect of mannan oligosaccharides on growth performance of challenged broilers. In: Proceedings $12^{\text {th }}$ European Poultry Conference, Supplement of World's Poult. Sci. J. 62, 319.

Porter Jr., R.E., 1998. Bacterial enteritides of poultry. Poult. Sci. 77, 1159-1165.

Rosen, G.D., 2007. Holo-analysis of the efficacy of Bio-Mos in broiler nutrition. Br. Poult. Sci. 48, 21-26.

Rostagno, M.H., Wesley, I.V. Trampel, D.W. \& Hurd, H.S., 2006. Salmonella prevalence in market-age turkeys on-farm and at slaughter. Poult. Sci. 85, 1838-1842.

Salim, H.M., Kang, H.K., Akter, N., Kim, D.W., Kim, J.H., Kim, M.J., Na, J.C., Jong, H.B., Choi, H.C., Suh, O.S. \& Kim, W.K., 2013. Supplementation of direct-fed microbials as an alternative to antibiotic on growth performance, immune response, cecal microbial population, and ileal morphology of broiler chickens. Poult. Sci. 92, 2084-2090.

Santin, E., Maiorka, A., Macari, M., Grecco, M., Sanchez, J.C., Okada, T.M. \& Myasaka, A.M., 2001. Performance and intestinal mucosa development of broiler chickens fed diets containing Saccharomyces cerevisiae cell wall. J. Appl. Poult. Res. 10, 236-244.

SAS, 2003. SAS Users Guide: Statistics. Version 9.1.3. SAS Institute, Cary, NC, USA.

Smith, D.L., Johnson, J.A., Harris, A.D., Furuno, J.P., Perencevich, E.N. \& Morris, J.G., 2003. Assessing risks for a pre-emergent pathogen: Virginiamycin use and the emergence of streptogram in resistance in Enterococcus faecium. Lancet Inf. Dis. 3, 241-249.

Spring, P., Wenk, C., Dawson, K.A. \& Newman, K.E., 2000. The effects of dietary mannanoligosaccharides on cecal parameters and the concentrations of enteric bacteria in the ceca of Salmonella-challenged broiler chicks. Poult. Sci. 79, 205-211.

Teo, A.Y.L. \& Tan, H.M., 2006. Effect of Bacillus subtilis PB6 (CLOSTAT) on broilers infected with a pathogenic strain of Escherichia coli. J. Appl. Poult. Res. 15, 229-235.

Teo, A.Y.L. \& Tan, H.M., 2007. Evaluation of the performance and Intestinal gut microflora of broilers fed on corn-soy diets supplemented with Bacillus subtilis PB6 (CloSTAT). J. Appl. Poult. Res. 16, 296-303.

Thongsong, B., Kalandakanond-Thongsong, S. \& Chavananikul, V., 2008. Effects of the addition of probiotic containing both bacteria and yeast or an antibiotic on performance parameters, mortality rate and antibiotic resid residue in broilers. Thai J. Vet. Med. 38, 17-26.

Tollefson, L., Angulo, F.J. \& Fedorka-Cray, P.J., 1998. National surveillance for antibiotic resistance in zoonotic enteric pathogens. Vet. Clin. N. America Food Anim. Prac. 14, 141-150.

Wilson, J., Tice, G., Brash, M.L. \& Hilaire, S., 2005. Manifestations of Clostridium perfringens and related bacterial enteritides in broiler chickens. World's Poult. Sci. J. 61, 435-449.

Yang, Y., Iji, P.A., Kocher, A., Mikkelsen, L.L. \& Choct, M., 2007. Effects of mannanoligosaccharide on growth performance, the development of gut microflora and gut function of broiler chickens raised on new litter. J. Appl. Poult. Res. 16, 280-288.

Yang, Y., lji, P.A., Kocher, A., Mikkelsen, L.L. \& Choct, M., 2008. Effects of dietary mannanoligosaccharide on growth performance, nutrient digestibility and gut development of broilers given different cereal based diets. J. Anim. Phys. Nutr. 92, 650-659.

Yang, Y., lji, P.A. \& Choct, M., 2009. Dietary modulation of gut microflora in broiler chickens: A review of the role of six kinds of alternatives to in-feed antibiotics. World's Poult. Sci. J. 65, 97-114.

Zhang, A.W., Lee, B.D., Lee, S.K., Lee, K.W., An, G.H., Song, K.B. \& Lee, C.H., 2005. Effects of yeast (Saccharomyces cerevisiae) cell components on growth performance, meat quality, and ileal mucosa development of broiler chicks. Poult. Sci. 84, 1015-1021. 